\title{
Legal-Juridical Analysis of the Basis and Impact of Harmful Contracts on the Relations of the Sides and the Third Parties under the Act 2014 of the Way of Implementing Financial Sentences
}

\author{
Mahboobeh Mina ${ }^{1}$, Mehdi Sokhanvar ${ }^{1}$, Davood Jahanbazi ${ }^{2} \&$ Seyyed Hoseyn Hoseyni Rechi ${ }^{3}$ \\ ${ }^{1}$ Department of Islamic and Private Law, Law and Political Science Faculty, Shiraz University, Shiraz, Iran \\ ${ }^{2}$ Department of Islamic and Private Law, Law and Political Science Faculty, Shiraz UniversityUniversity of Qom, \\ Qom, Iran \\ ${ }^{3}$ Department of Islamic and Private Law, Humanities Faculty, Islamic Azad University of Marvdasht, Shiraz, Iran \\ Correspondence: Mehdi Sokhanvar, Department of Islamic and Private Law, Law and Political Science Faculty, \\ Shiraz University, Shiraz, Iran. E-mail: Mehdisokhanvar28@yahoo.com
}

Received: January 19, 2017

Accepted: February 13, 2017

Online Published: February 28, 2017

doi:10.5539/jpl.v10n2p188

URL: https://doi.org/10.5539/jpl.v10n2p188

\begin{abstract}
Given the relativity principle of contracts their impacts in proportion to third parties are an exceptional issue. In a possible assumption there is a possibility of harm and damage to a third party because of the contract between two people. In our juridical texts, some religious experts have sporadically in a topic of jurisprudence stated the instances of these contracts and have considered two theories of validity and invalidity about them. On the basis of this assumption, although the law of the way of implementing financial sentences considered hanged in 2014 but its 21 st article with a bit of expansion has considered the former result. Therefore concerning these contracts by considering the valuable rule of the principle of no harm, we can accept the theory of relative lack of influence. Given the importance and role of the contracts in the life of community members and the lack of determining the influence of such contracts in legal and juridical texts the analysis of these impacts seems to be necessary. In the present article by analyzing the subject in legal and juridical texts of Iran the influence of these contracts in the relation between the parties and in proportion to third party is analyzed.
\end{abstract}

Keywords: third parties, relative lack of influence, security against fault in title, unjustified usage, exchequer benefits and non-exchequer

\section{Introduction}

Today the significance of contracts and their role in the life of the people is quite evident to everyone. Given the position of contracts and the safety of the economic contracts among the members of a society on one hand and the negation of causing damage and harm to others on the other hand necessitates the conduction of analysis in terms of contracts causing damage to third parties which creates a nexus among ethics, law and economy. Contract causing damage to third parties is not only a legal and juridical issue, but it is related to the economy as well as ethics. Therefore the precise analysis and determination of the influences of these contracts and the legislation of efficient and apposite by the legislator can facilitate the safety of economic and trade relations as well as creating order in society. On the basis of the contractual freedom principle people can conduct transactions in any way they like. And also on the basis of the relativity of the contracts the influences of the contracts are efficient between the sides and their deputies and basically the contracts cannot pose any influence on third parties. In some cases there is a possibility of imposing damage and harm to the third party because of the transaction between the sides. Given the subject discussed in jurisprudence, it can be argued that the first religious expert who has referred to it as a distinct issue is Mula Muhammad Naraghi in the book Masharegolahkam where he has mentioned it under the title of contracts causing harm and analyzed it. Considering the rule of dominance and sovereignty and freedom of will principally the indebted person cannot be banned from transactions and the management of his properties and belongings. But it is possible to assume that the indebted person does not have sufficient property and belonging to pay for the debts but given the condition and the payment of the debts which are upon him to pay perform transactions render him more distressful and make the provision of the right of the creditors more difficult or impossible and as a result cause 
damage and harm. In some cases it is possible that the heirs without fulfilling the debts concerning the deceased heirloom make some possessions in it that cause damage to the creditors of the deceased. Now by considering the religious texts and rules and the available regulations such as the precious principle of no harm, the unknown view of the religious experts, 40th principle of the constitution and the latest changes of the law in this respect which has led to the acceptance of relative lack of influence rule, what are the influences of these transactions in the relation between the sides> what are the influences of this transaction in the relation between sides in proportion to the third party?

\section{The Validity of the Transaction between the Parties}

As stated earlier contracts causing damage to third parties also between the sides of them are valid and influential the same as other contracts and have their own influences and only for the protection of the rights and interests of the creditors against them lack legal influence and cannot be attributed. It can be stated that the main influence of every contract is the responsiveness of the sides of the contract to the contract parts and the principle of the authority of the contract is ruling over the sides of the party. In case the warrantor does not fulfill the contractual obligations the warrantee can refer to the court or other valid authorities and call for the compulsion of the warrantor or the compensation for the harm caused by the lack of fulfilling the commitment (articles 221 and 237 civil law) From ethical vantage point fulfilling the commitment and doing the promise of the contract as an optimal issue ad from social perspective it is in accord with the stability of the contracts and the security and order of the economic relations of the people in the community. In our religious texts to explain the obligation of contracts are originated from the sacred Ayah $<$ fulfill the promises $>$ has been attributed (Hosseyni Maragi, 1996; Muhammad Hassan Najafi, 1983; Morteza Ben Muhammad Amin Ansari, 1994). In our law, this fact can be interpreted from article 219 of the civil law. This article states that: <contracts concluded on the basis of the law are obligatory for the parties as well as their deputies unless by the agreement of the sides or because of the law become nullified>. Some of the legal experts believe that from this article the principle of the obligation of contracts cannot be interpreted, but in terms of fulfilling the commitments and the obligation of observing the parts of the contract it is more general that obligatory and valid. This view has some supporters in jurisprudence and some of the religious experts have interpreted from the Ayah < fulfill the promises $>$ the obligation of fulfilling the content of the contract whether it is valid or obligatory. But in contrast legal experts believe that this article only discusses the obligation of contracts in irrevocable contract. But it should be mentioned that in addition to the commitment and obligation of the sides to observe the contents of the contract whether it is a revocable or obligatory if there is a suspicion about the contract whether it is revocable or obligatory that contract is revocable unless the opposite is proved. Therefore the contracts causing damage to the third parties are valid and influential between the sides and have the same influence as other contracts.

\section{Legal Basis Analysis of the Transferee}

As mentioned earlier the contracts causing damage to the third parties are not only attributable against the third party, but in the relation between the sides of them are valid and influential. On the basis of the aforementioned issues the third party person (creditor) according to the new act of financial sentences passed in 2014 without considering the influence and impact of the contract can refer to the transferee and call for the compensation of the lost property. In contracts the mutual consent of the sides makes the commitments stand against each other and correlation occur between them (Muhammad Jafar Langrudi, 2006). Any one of the sides of the contract transfers money or fulfills a commitment that in response earn what was intended from the contract and at the end two returns should not be extracted from one property. Because in such cases batter justice is disrupted and it is in contrast with the intention of the sides of the contract or the sides that to earn the intended return for which a return has been provided. By the reference of creditor to the transferee and calling for the credit the transferee would be bereft of all or part of his property and since he has paid the return he can refer to the transferring party to pay for the amount of damage and commitment or the case of the contract being deprived from. Now the question is on the basis of what principle and reason can the transferee refer to the transferring party? We would discuss this basis in the following part (Naser Katuzian, 2013).

\subsection{Security against Fault in Title}

The term guaranty refers to taking responsibility and bail-out. The word perception in the words of jurisprudence refers to damage and preparation. In the civil law the word perception in article 607 states that: <security of the customer or the buyer in terms of perceiving the article or the cost and in case of legally belonging then it is valid $>$ the term perception has been defined as a preparation. The term security against fault in title has been used by some of the religious experts as a synonym for commitment security (Zeinodin ben Ali Ameli, 1992) which is not correct and accurately they are differentiated in the law. The legislator in the second part of the 
article 362 and items 390 and 391 of the civil law refers to it. Therefore, it can be stated that the purpose of the security against fault in title is that if in replaced contracts one of the replaced properties is the property of someone else the side who has received a benefit for that should return it and in fact the responsibility is upon the person who has transferred the other's property to someone else. The mere reference to the security against fault in title in the purchase contract is no apposite reasoning because it is the most popular contract among people. Therefore, the legislator has brought the rules about other contracts in this contract and can be expanded to other contracts. Therefore the security against fault in title is not limited to the object of sale or the price in sale contract and it is one of the rules of batter contracts which is mentioned in the civil law under the sale subject and has been referred to by some legal experts. In our law the security against fault in title is the definite object. In case the object of sale or the price is generally obligatory since in our law the sale contract is possessive and the selection and the transfer of the object of sale is not a separate and independent possession, but it is the continuation of a commitment that the seller has obtained during the contract and it can be stated that the seller has not fulfilled his commitments and the buyer can oblige him to selection and submission of the contract object from the court (Naser Katuzian, 1988). Therefore, given the aforementioned explanations it should be stated that in contracts causing damage to the third parties by the reference of the creditor to the transferee and demanding for the damaged right from the definite object of the contract it can be stated that it is the same as transactions where the sale object has become possessed by someone else. In these cases the transferring side on the basis of the security against fault in title is responsible and the transferee on the basis of the same principle refers to him. Therefore, the transferring side (debtor) is responsible to secure the fault in the title to the other side of the contract with the (transferee) and need to return the contract sale object.

\subsubsection{The Impact of Security against Fault in Title}

As stated earlier by the reference of the creditor to the transferee he can also refer to the corresponding dealing side (debtor). In terms of the responsibility of the seller to return the price of the sale object in our religious texts in cases where the definite object belonging to someone else is sold and the owner does not authorize it there is a difference of opinion. Some religious experts in this respect believe that the knowledge of the customer about the eligibility of someone else for the ownership of the transaction object and lack of knowledge in this respect and in the case of the knowledge and awareness the customer in cases where the exact price of the sale object is left or lost has been differentiated. In case of the ignorance of the customer of the merit of the sale object to someone else it can be stated that the majority of the religious experts believe that the customer can refer to the seller for the return of the price of the sale object (Muhammad ben Hassan Ben Yusef Helli, 2008). Then on the basis of possession guarantee (it remains on hand whatever the person receives until it is fulfilled (returned) the vender is responsible for the receiving price and in case of existence the remaining amount should be returned to the buyer and in case of loss the customer can demand for the same amount (the same price) of it (Muhsen Tabatabai Hakim, Nahjolbalage). Because the deal because of lack of permission by the owner is cancelled and there would be no legal cause and reason for the departure of the price from the ownership of the customer. In case the customer is aware of the belonging of the sale object to someone else in this case some of the religious experts believe in the difference between the existence of the same as object price and its waste and stated that in case of the existence of the same amount of the price the customer has the right to refer to the vendor to demand for the price. Because there is no religious or legal reason to transfer the ownership of the available exact price from the customer to the vendor unless the sale which has occurred illegally between the sides and the corrupt sale has no effect on the ownership therefore, the customer can return the exact price. But in case the exact price is wasted and the customer is aware of the merit of the other person to the possession of the sale object, then he would have no right to refer to the customer because in fact the act of the customer is sort of allotting dominance to the vendor by himself which leads to the ownership of the vendor to the price. This view is not approved by some of the recent religious experts and has been criticized and has stated that surrendering the price by the customer to the vendor is not a free dominance and the possession of the price is in return of an exchange and this surrendering has occurrence in the continuation of the contract between the sides and has happened by the intention of fulfilling the commitment of the contract between the sides of the contract although the vendor pretends illegally the ownership of the sales and the customer is aware of it. But this illegal intention does not make the ownership free and the possession guarantee still exists and is not allocated. Therefore, the customer would have the right to refer to the vendor to return the exact price. Our legislator in the article 391 of the civil law has stated in this issue. Therefore, it should be stated that on the basis of possession guarantee it remains on hand whatever the person receives until it is fulfilled (returned) principle the guarantee and responsibility of the vendor still exist and the customer in all assumptions can refer to the vendor to receive the price.

In terms of the inflicted damage as stated in the civil law the influence of the possession guarantee is not limited 
to the rejection of price and the customer in terms of ignorance can refer to the price reception to receive damage to the vendor. And by damage all the expenses, excluding the cost of the sale object such as dealer wage, transport expenses and in case of the waste of the sales object the additional price of the known price etc. that the ignorant customer has experienced in this transaction. In terms of the merit of the transferee to demand for the damage compensation in addition to the exact price the basis price has been presented by the religious scholars such as: A) delusion principle which is one of the rules referred to the civil responsibility and it is extracted from the prophet words $<$ the deluded refers to the person who had deluded him $>$ according to this principle if a person delude another person and as a result of this delusion a damage is inflicted on him the deluder is responsible for the compensation of the deluded person. Some of the religious experts consider referable only when the deluded person is unaware of the merit of the possession1to2 someone else (Muhammad Kazem Ben Hussein Khorasani, 1985). But in contrast to some other religious experts consider the mere act of delusion of the deluder as the sufficient cause and believe that the knowledge and ignorance of the deluder is inefficient in the influence of his guarantee. However, regardless of the difference in terms of the knowledge and the ignorance of the vendor to impose the principle of delusion the ignorance of the customer is essential. B) The no harm principle, on the basis of this principle the ignorant customer can refer to the vendor to demand for the compensation Because, otherwise he would experience damage and harm and it is necessary to prevent damage and harm. But in the opinion of some religious experts referring to the nor harm principle is not apposite to prove the right of the customer to the vendor to receive compensation and is faulty. Because the no harm principle is incapable of proving the judgment and only has the capacity of negating the harm principle and in cases where because of the lack of fraud a sentence damage is inflicted on someone the nor harm principle cannot be implemented to prove the responsibility of the vendor in terms of the compensation for damage6. C) The principle of causality, according to this principle anyone who does not waste the property of others by purpose, but indirectly cause the waste of others' property, whether consciously and by purpose or not is responsible for the compensation of the inflicted damage. In causality whether by knowledge or without knowledge and whether by a positive action, such as dropping a stone in the public passage or quitting a responsibility which is legally or on the basis of a contract his responsibility at any way need to make compensation for the damage. The legislator has mentioned it in article 307 and 331 of the civil law. In substantiating the responsibility of the vendor in terms of the inflicted damage on the ignorant customer it should be stated that one who sells the property of others while the customer is ignorant of this fact and then as a result of the reference of the owner and the refund of the article and the compensation the customer experiences damage in fact the seller has been the cause of the damage and therefore the final guarantee is upon the seller and the customer can refer to the vendor for the damage compensation (Muhammad Kazem Tabatabaee Yazdi, 2000). This reasoning has been criticized by some of the religious experts and believe that the causality principle can be applied for cases where the cause (the cause of inflicting damage) and harm, is not done by a conscious person, but in terms of the vendor the total cause of inflicting the damage on the customer is not, but the act of the vendor is the cause of creating inventive in the customer to tolerate the damage therefore, the causality principle would not be administered. 8 But in answer to this reasoning as mentioned by some of the religious experts it should be stated that although the customer is the steward of alliance and damage, but it is weaker than the cause (Abolgasem ben Muhammad Hassan Gilani, 1992) and in the assumption that the cause is stronger than steward it should be stated that the guarantee is about the cause and not the steward that is mentioned by the legislator in article 332. The author believes that at the most by overlooking the possibility of guarantee principle in terms of the no harm principle and that in the term delusion of the delusion principle a type of intention is covert and shows the prior knowledge and intention of the deluder the causality principle be selected as the basic principle of substantiating the sales guarantee to the inflicted damage on the customer. Although it is possible that in cases where the transaction is done with bad intention the delusion principle can also be applied as the reference to demand compensation. Therefore, by the reference of the creditor to the transferee and demanding for his right of the exact object of the transaction, it can be stated that it is like cases where the object of the transaction belongs to someone else and the transferee by considering the rules of the possession guarantee can refer to the transferring side to receive the payment compensation and in case of ignorance refer for the damage collection.

\subsection{Unjustified Usage}

No one can earn without causing cost or damage without the existence of a legal cause that is under the support of law. Therefore, it can be stated that it has a social and ethical basis and it is in accord with the most significant ideal of law that is justice. As stated earlier as a result of the reference of the creditor to the transferee and demanding the debt he can refer to his dealing side (transferring side). In terms of the basis and description of the reference of the transferee to the debtor what title can be used it seems that it can be stated that the transferee on the basis of the unjustified usage can refer to the other side of the contract. In our objective law, there is no 
reference to the unjustified usage. And only in the trade law of legislator in article 319 there is a reference to this principle. But legal experts in their writings have stated this principle and its rules and influences and conditions. Dr. Langrudi in law terminology book states under the term <unjustified possession>, < unjustified possession refers to the following instances: A) transferring the property of someone to another one without legal cause of the country such as the lottery winner who possesses without reason. B) One who without reason takes the possession of others' this is also referred to as unjustified possession such as a usurper and a robber and in this meaning in jurisprudence usurping the property of wasted property has been implemented (Muhammad Jafar Langrudi, Terminology of law). Some of the legal experts have stated the concept of the principle as follows: $<$ unjustified usage refers to that a person without a legal cause or a contract possesses something by the damage of another person and in other words a person in an unfair way possesses without a legal basis and with the damage to others' property on the basis of justice and fairness and the accepted principle of most of the countries all of the exact property or the same as it should be returned to the person who has experienced the damage> (Mirabolfattah Ben alihasani Maragi, Alanavinol Feghi). In terms of the possession it should be stated that the ruling principles and regulation on the economic and legal system of every society show that earning property is legal and valid in what ways and people need to arrange their legal and economic relations accordingly that the legislator has referred to it in article 29 and 140 of the civil law. As can be interpreted from these articles earning property and the means of ownership might be done via contracts, agreements and law. Some scholars consider $<$ permission $>$ as the fourth source of the legal advocating. So that the right of benefiting or sharing is caused by the contract or merely the permission of the owner (Seyyed Mahdi Navaie, 2009). The title unjustified possession or unfair earning in out juridical texts next to other elements of obligatory guarantee as a special source and independent have not been presented for the guarantee. Some of the religious experts refer to possession guarantee, guarantee because of the waste of the guarantee because of delusion, the guarantee of cause of waste before control and the guarantee dominated by corrupt contract (Seyyed Hussein Safaee, 2007). But it should be stated that this cannot be the cause of lack of acceptance of this principle in our jurisprudence. Paying attention to the concept of this principle which is the preservation of the balance between belongings and the fact that no one can without legal cause and by the damage to others make earnings and this principle exists briefly in our jurisprudence and has been accepted. Although it has not been referred to as a general principle causing guarantee it should be stated that there are rules and foundations that cover many cases of unjustified usage. Therefore, it causes that in juridical and legal texts of ours the need of unjustified usage principle as an independent source for the guarantee and commitment is not felt (Habibollah Rahim, 2009). One of the rule which is considered to identify possession guarantee principle: A) possession guarantee principle, this principle is extracted from the prophet words» (it remains on hand whatever the person receives until it is fulfilled (returned) (Mirza Hassan Mohaddes Nuri, 1987). On the basis of this rule anyone who capture the property of another one should return it to its owner and occupier in case of waste or damage to the property should make compensation for the inflicted damage. On the basis of the elements of the rule it can be stated that in the possession guarantee there is no difference between elements of knowledge and ignorance and violation and extremism and in both conditions the occupier is responsible. The difference between possession guarantee and occupation is in terms of intentional and adversary where there is an element of intention in occupation. In these cases the usurper or occupier in addition to the exact property is responsible for the obtained and non-obtained benefits and should compensate them. This famous opinion of the religious experts has been mentioned in the article 261 of the civil law. Some of the scholars in reasoning the guarantee have stated the benefits and that the exact and the benefit in the accuracy of the title of the ownership there is no difference and the benefit in following the exact property under the dominance and possession such as the rent contract where the possession of object accompanies the possession of benefit. But despite that in the opinion of some religious experts possession guarantee is just for the wealthy. That is the purpose of the term «اء|l|)in religious quotations returning the exact of what has been received and in case of inability the same or the price of it and it axiomatic that the return of the possessed is not logical for the benefit. Therefore, the possession guarantee is allocated to the wealthy. And the benefits guarantee is beyond the rule (Abolgasem Musavi Khoie, 1992). But some other religious experts in this case have considered differentiation and have considered the difference between the potential and practical benefits and have accepted the dominance in the case of the benefits which have potential and external existence, but the possession guarantee over potential benefits which do not have an external existence as difficult (Mirabolfattah Ben alihasani Maragi, Alanavinol Feghi). B: The vindication principle is another case in our religious texts which has engaged many cases of unjustified usage. The elements of this principle has been mentioned in the words of many religious experts Sheik Ansari in the book Makaseb under the explanation of the principle of any contract that is accurate and committing provides some statements in brief: any job done for another person 'so that it is in line with his wishes the same value of that should be returned 
(Morteza Ben Muhammad Amin Ansari, 1994). Therefore, in his opinion in case a person under the order of another one does something to facilitate his work he would deserve to receive the wage and return of his work. And also some of the religious experts have stated that if a person gives a garment to someone and tell him to wash it and does not determined the wage for it and even does not determine it implicitly and that person washes the clothes then he would deserve the wage (Abujafar Muhammad ben Toosi, 1986). Similarly some experts have also referred to the respect rule (Abujafar abolhasan Tusi, 2008). According to this rule the property and the action of the Muslim is respectable and should not be freely occupied, violated or transgressed (Muhammad Kazem Mostafavi, 2000). Our civil law in articles 336 and 337 under the vindication topic which is one of the requirements of obligatory guarantee has mentioned. In addition to the abovementioned views in terms of the unjustified usage in our rule we might refer to a number of cases where the prevention of unjustified usage and unfair earning has been officially recognized such as: article 319 of the trade law is the only subject rule that explicitly refer to the unjustified use is the article 319 of the civil law. Article 318 of the trade law and parts 33 and 172 of the civil law and the principle 49 of the constitution are among them. Every foundation requires elements and bases for formation that we refer to them as follows: A) possession, in case a person earns a property or benefit he is said to have earned. In the definition of the property it has been stated that the property is something that can be traded and in exchange of it money or something else is given and has two basic conditions: first, it is useful, and fulfill a need either material need or spiritual. Second, can be allocated to a certain person or nation. About this question that whether the possession is dependent only on earning more finance and adding to the property or not some of the legal experts believe that in addition to the financial value in a place where the person obtains spiritual benefit from another person, learns a career or a science according to the current life requirements the justice requires to respect the creator's work and no one should be able to unfairly cause damage or take benefit from it without paying anything in return (Naser Katuzian, Out of the contract obligations). Therefore, it can be stated that as far as it is close to money it is enough. Similarly since the debts are considered as the bases of the personal belongings the same as credits and properties this fact should be considered that in addition to the positive aspect of the rise of the property such as the time when the user earns some property and in cases when the amount of the debts of the person is reduced or a damage or expense is diverted from him it cannot be said that the person has earned (Seyyed Hassan Safaie \& Habibollah Rahimi, Civil law responsibility). B) Reduction of property, in contrast to the rise of property the property of another one is reduced or that a work is not paid. So that the sufferer can demand for compensation for what he has experienced lunjustly (Naser Katuzian, properties and ownership). C) The relation between the rise and fall of the property is the third condition of the use of unjustified usage is the existence of relation between rise and fall of the property.

\subsubsection{The Influence of Unjustified Regulation}

As stated earlier the most significant reference of the unjustified usage principle is the sacred Ayah"don't feed on illegal ways". On the basis of this sacred Ayah eating the other's property is negated and the word eating is in line with the (belongings) which has come afterwards and any type of occupation and domination is negated (Ahmad Ali Mahmadi Vagef, 2010). In the relationship between the transferee and the transferring as the sides of the contract in addition to the rules about the guarantee of possession that was stated on the basis of the unjustified principle we can refer to the transferring party. By the reference of the creditor (third party) to the transferee and receiving his credit from his property the transferee loses whatever he has earned in the transaction and has paid a return and in this way his share is reduced. Therefore, this can be an instance of the

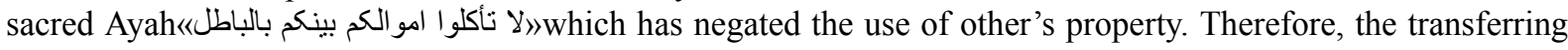
party is responsible for the property and if the property is the exact property and if not the price of it need to be paid. Now the question is that whether the transferee can receive the damage cost in addition to the return of the property from the transferring sides?

In this case there should be a difference between being returnable and non-returnable so that in case the transferee paid a return for the returnee the transferee under the principle of causality, delusion or no harm principle. In terms of the reference of the transferee in proportion to the return benefits payment in his relation with transferring party can be stated that as far as the transferee has not referred to the creditor the transferee on the basis of the mutual consent principle of the contracts and that the contracts are domination returnee in the relation between himself and the transferee the owner is the receptive return and has occupied his property and in case this return is receptive <objective $>$ the benefit in observation of objective belongs to the transferee. But since the time creditor refers to the transferee and demand his credit from the (debtor) to vindicate the contract object from the transferee and it can be stated that there is no cause for the return by the transferee to the transferring party and the return without the cause and legal and juridical cause is in the possession of the 
transferring party and is responsible for the interests of him. The other point that should be referred at the end of this subject is that in cases where the transaction between the transferee and the transferring party is not returnable and the transference of the property has been free of charge such as gifting transferee under the principle of »any contract whose accurate for does not require payment to the other its corrupt for is not obligatory either cannot refer to the transferring party. This principle and its opposite have been referred a lot in our religious texts by several religious experts.456. That is any transaction whose accuracy does not cause guarantee it would not lead to the guarantee of its corruption. That is in a contract where the receiving party in return of reception does not accept the returnee property in case of the corruption of the contract since has not paid any return cannot refer to the transferring party. Some of the legal experts have defined the principle as follows: <any contract whose valid does not lead to the preparation of property to the exact property whether under authenticated contract that is not possessive or because of the fact that the domination is free of charge, its corruption does not make the receiver responsible for the fulfillment of the exact property> (Hamid Egri, Akbari Izadifard, 2010). In this respect some of the legal experts have not accepted the possession guarantee in cases where the intended property belongs to someone else because in return for the dominance nothing has been received and have state that the gifting side only provides the receiver with the property and does not guarantee his ownership therefore if the gift receiver then the gift giver would not have any responsibility in compensating for the damage. Although they have not negated the responsibility of the gift provider and his obligatory responsibility in terms of the damage inflicted on the gift receiver and on the obligatory guarantee has considered him as the responsible party (Naser Katuzian, 2011). Therefore in the opinion of the author in cases where the transference of the property in relation between the transferring party and the transferee has been free it can be stated that on the basis of the principle »any contract whose accurate for does not require payment to the other its corrupt for is not obligatory either transferee according to none of the possession guarantee or the unjustified principle can refer to the transferring party.

\section{The Influence of the Contracts Causing Damage on the Relations between the Third Party and the Sides}

According to what was earlier stated and on the basis of the view selected about these transaction the contracts causing damage to the third parties is influential in the relation between the sides but cannot be referred in the case of third party. The third party (creditor) regardless of this fact can refer to the transferee and consider the property of the property of transferring party as the property of debtor and vindicated his credit from it. Therefore, it can be stated that the main side of the creditor is the transferee and the creditor can by referring to him vindicated to the right amount from the property in this part we discuss the influence of the damage causing contracts on the relation between the third party (creditor) and the way it is vindicated.

\subsection{The Presence of the Exact Contract Object in the Property of the Transferee}

By the assumption that the contract object has been the exact in between the transferring party and the transferee and it still exists in the property of the transferee on the basis of the article 21 of the civil law passed in 2014 and that the contract cannot be referred it can be stated that the creditor can consider the same as the property of the debtor and vindicate the credit from the property. Article 21 of the civil law passed in 2014 states that: <...in this case the exact property and in case of waste or loss the same or the price is demanded as the fine from the receiver and will be used to vindicate the subject of the judgment $>$. In this article this right is recognized for the creditor to vindicate his credit from the exact property of the transferee and in case it is not available and it is wasted the same or the price of it be demanded. On the one hand the ownership of the transferee is recognized and on the other hand the creditor can regardless of that for the credit from the transferring party (debtor) vindicate the same or the price of the contract object. The other point that can be referred to is that the creditor can refer to the transferee as much as his credit and in case some part of the property is left it belongs to the transferee the same as the creditor after vindicating the property of contract if cannot obtain the whole of the property should refer to the debtor (transferring). Because the creditor has received his credit and in terms of the rest no damage is concerned for the creditor and the contract is in influence for the sides. But in the relation between the transferring and the transferee it can be stated that since the contract is divided into two parts of accurate and inaccurate the transferee can on the basis of the option of discrimination issue annul the contract even for the accurate part and it is in action in return contracts but not in free of charge contracts.

\subsubsection{Vindication of Benefits}

On the basis of the various definition presented by legal experts about the benefit it can be stated that the similarity point of them is that the benefit of it is dependent on the exact object and it is obtained gradually (Seyyed Hussein Safaee, 2004). and sometime it is possible that it has external and objective existence such as the tree fruits and sometimes non-material such as the benefit of residing at home. Benefit has been divided into 
different types that the most important ones are referred: A) Separate benefits, B) Connected benefits. In our legal and juridical texts in several cases such as the influence of cancelation and annulment (article 287 of the civil law) and the result of the mortgaged property (article 784 of the civil law) the legislator has differentiated between the separate and connected benefits and considered different influences that the legislator refers to it in article 287 of the civil law C) the exchequer benefits refers to the benefits of the exact property which has been used and stated that if someone occupies the other's property and make use of it during that (or benefit over a period of the occupation) those benefits are referred to as the exchequer benefits $>$ (Muhammad Jafar Langrudi, 2009) the same as a person who occupies another person's house and resides there or rents it to someone else. D) Non-exchequer benefits refer to benefits that have not been used and it has been defined they are accessible benefits that the occupying person has not benefited from the property $>$ (Taheri, Habibollah, 1997) such as the person who locks the door of the house occupied. In terms of the vindication of creditor of the contract benefit and the possibility of referring to the transferee in proportion of guarantee of the benefits given the fact that the contract is nullified in the eyes of the creditors and cannot be referred article 21 of the civil law passed in 2014 the same as the article 4 of the former law passed in 1998 is inactive. First in observation of the principle of benefit from object of the contract this right can be identified for the creditor but it seems that this issue should not be accepted as absolute and should be differentiated from other issues. The principle (following and observing the principle) which has been less mentioned in the juridical texts and has been referred to by the religious experts (Abujafar abolhasan Tusi, 2008).

This principle denotes that the benefits obtained from the properties observe the ownership principle. Therefore anyone who is the owner of the exact object of the property would be the owner of its (Muhammad Kazem Mostafavi, 2000) benefits in our juridical texts in terms of the guarantee about the benefits there is a difference of opinion but the major view of the religious experts by referring to various reasons such as the possession guarantee principle and respecting the property and the absolute action. In our law by the attribution of the article 320 of the civil law it can be stated that in our law the guarantee in terms of the benefits either separate or the connected and the exchequer and non-exchequer has been accepted. In this respect some of the scholars have accurately justified the basis of usurper guarantee about the benefits of the exchequer and in the case of non-exchequer guarantee is justified on the basis of coalition (Hamid Egri \& Akbari Izadifard, 2010). Now the question remains that, can the creditor in addition to the exact property to be transferred vindicate his benefits of it. And given the fact that the concluded contract is cancelled in the eyes of the creditor is the transferee responsible for the benefits?

In answer first it should be mentioned that the creditor about the property of the debtor (transferring) does not have objective right and he owes him and he is obliged to pay it and it is a religious right and as stated by the legal experts the requirements of creating the objective rights is limited to special cases and the inclusion of the objective law is determined by the law (Naser Katuzian, properties and ownership). Because in case the creditor had the objective right of the type of ownership to the property he could ask for his property in anyone's possession and in fact the knowledge and ignorance of the transferring (debtor) and the transferee does not influence the guarantee compared to object and the benefit. In terms of the connected benefits as mentioned in it definition since they are not separated from the object and always have value he same as the object then it is axiomatic that by the reference of the creditor they are vindicated along the object of the property. Separate benefits which have acquired external existence by the assumption that the exact object of the contract is still in debt in observation of the object can in case of the object in paying for the credit be vindicated by the creditor. But in terms of the exchequer and non-exchequer it seems that the condition of the transferee and the usurper be compared there is no chance of reference by the creditor to the transferee to vindicate the exchequer is difficult. Because as far as the creditor has not referred to the transferee to vindicate his credit given the fact of the influence of the mutual contract the transferee is the owner and the occupation of the object is the same as the ownership of his property but by the reference of the creditor to the transferee the creditor can vindicate his right from the object of the property the same as the time the possession of the object is in the hand of the transferring (debtor) could refer only to the present properties. Therefore as mentioned earlier the creditor has no objective right over the transferring property so that can vindicate the benefits from the exchequer and non-exchequer property and in fact the legislator in the article 21 of the civil law passed in 2014 has authorized the creditor to vindicate his credit from the contract object. Even by this assumption that we consider the property to the debtor but again the debtor who is the owner of the object of the transfer is not responsible for the benefits. Therefore, although the contract cannot be referred in front of the creditor and it is annulled by judgment but it cannot be compared with the possession and dominance guarantee and attribute all features of the usurping. 


\subsection{Lack of the Existence of the Transferring Object in the Ownership of Transferee}

\subsubsection{Lack of the Influence of Object Because of Its Waste}

In cases where there is no exact object of the transaction in the property of the transferee the creditor in these cases on the basis of the article 21 of the civil law passed in 2014 by considering the fact that the contract cannot be referred against the creditor and by considering the basis of the case which is the compensation for the damage and preserving the rights and benefits of the creditor therefore the legislator has allotted the creditor to refer to the transferee and in case the exact object is present vindicate his credit from it and in case the exact is not in the possession vindicate his right from the same object or its price. In fact it can be stated that the legislator has ascribed influences such as usurping on the contract but it should be stated that the influence of usurping cannot be ascribed totally to it. It can be stated that the most significant responsibility of the usurper is to return the exact object which has been mentioned in our legal and juridical texts (Zeinodin ben Ali Ameli, 1992).The writer of Jawahir al kalam in reference to the religious quotation «مالغصب states that»: as long as the usurped property exists it is obligatory to be returned (Muhammad Hassan Najafi, 1983). Legal experts have also explained this issue in their writings that the usurper in case of the existence of the object should return the usurped property (Mehrab Darabpur, 2008). This obligation is prior to other obligations of the usurper that is by the existence of the object the usurper cannot refrain from returning the object and ask the owner to get the equal and the price of it and the owner by this condition does not have the right to demand the price. Because the responsibility of the usurper is to return the exact object the article 311 of the civil law states in this respect that $<$ usurper should return the property of the one usurped exactly>.

In the subject under the discussion this issue is axiomatic that by the existence of the exact object the creditor can vindicate only for the exact object and cannot demand a different object from the transferee and refer to other properties of him if the usurper does some actions in terms of the usurped property and increase the value of the usurped property the usurped does not have the right to demand the wage of the action carried out. For example if the usurper change a gold bar into necklace or plough the land after usurping has no right to demand the added price. Article 314 of the civil law states that therefore as a result of the usurping of the usurped property which has led to an addition the belonging added quality of the usurped property belongs to the party whose property has been usurped and the quantity depends to the usurper (Ahmad Ali Mahmadi Vagef, 2010). In terms of the discussed issue it can be stated that the transferee makes usurpation in the property so that increases the price of the property the transferee cannot be deprived of it and in case the addition is objective and for example about the transaction of a house and after that the usurper add door and window and water tank (by the assumption of the separation of the object) in comparison with the first usurpation it can be stated that this addition belongs to the transferee and cannot be vindicated by the creditor. In the assumption that the transferee has caused the addition of the price if the rules of the article 314 of the civil law in terms of the transferee it is not in accord with the legal justice. Because it seems that in terms of the vindication of the credit from the object or the same or the price the transferee is under the judgment of usurper and all influences of the usurpation cannot be levied on the usurper. Therefore, it can be stated that on the basis of the respect principle to the absolute property and action the transferee on the basis of the principle of unjustified usage the transferee can refer to the creditor. Any way by considering the article 21 of the financial law passed in 2014 in case the exact object is not in the ownership of the transferee the creditor can vindicate from the same or the price of it. The rule of this article is the same as the statement of article 311 of the civil law therefore, in case the exact property that is not in the ownership of transferee is exemplary and if it is monetary it price can be vindicated. In terms of the precious usurped property religious experts have diverse views: some believe that the usurper should pay the price of the day of usurpation and some believe that the usurper should pay for the time of waste because from this time the responsibility of the usurper starts Mohageghelli (Bojnordiye Mosavi, Hasanebne Aga Bozorg, 1998) consider this view uphold by manyl. Some others believe that the usurper is responsible for the time of the waste because from the time of usurpation until the usurper has been responsible for the return of the object and it is at the time of usurpation that the price is upon the usurper (Ali eben Hassan Karaki, 1993) In the opinion of some others the usurper is responsible for the highest price from the waste until return the statement of the shahid Avval is as follows: <the highest price between the time of usurpation and the time of return> (Muhammad ebnemaki Ameli, 1989). Some others consider the usurper responsible to pay for the day price of the object (Muhammad eben Muhammad tagi Bahrololum, 1982) and some others believe that the usurper is responsible for the highest price (Tabatabayi Haeri, Seyyed Aliebne Mohammad, 1997). In this respect there is a difference of opinion among the legal experts some of the legal experts believe that the usurper should pay for the day price and some other believe that the judge should judge on the basis of the day price (Muhammad Jafar Langrudi, 2007). But in the opinion of some others the usurper is responsible for the day of waste and any 
change in terms of the price has no effect on the responsibility of the usurper. But since in the rise of the prices it is not for the benefit of the owner and it does not seem fair that it should be stated whenever the price of the time of return is more than the price of the time of waste the owner can demand for the difference of prices under the causality and civil responsibility from the usuroer (Seyyed Hussein Safaee, 2007). Concerning the subject under the study it can be stated that in case if the waste of the exact object the creditor cannot vindicate the price of the day of return from the transferee because the creditor has the right of reference to the object in the original condition and has more right than that to the transferee and the responsibility of the usurper should not be considered the same as transferee and since the ownership of the transferee has been considered valid it can be stated that the transferee is responsible for the payment of the object in the original condition. Now in case the price of the waste time and the return of the exact object is not the same transferee under the principle of certain action and the forbiddance of it and on the basis of the unjustified usage to the transferring can refer for this additional part. On the other hand it is more reasonable that transferee be responsible for the time when the object is returned to the transferee.

\subsubsection{Lack of the Object in the Influence of Its Transference}

According to the article 21 of the civil law in case of the waste or transference ... it can be stated that the exact object of the contract by the transferee is transferred to someone else. On the one hand identifying the fact that creditor can refer to the second transferee is difficult and is not in accord with the legal rules. In article 21 of the civil law passed in 2014 the reference of the creditor to the second transferee has not been mentioned. And this issue is in accord with the security and stability of the contracts. In these cases it seems that it can be said that this case is the same as the excuse of the return of the object of the contract or that consider it as the judgment of waste and order for the payment of the same or the price and should not be confused with the owner right on the usurped property. Therefore, by considering the possibility of reference to the transferee first by the law in these cases the creditor can refer to the first transferee for the vindication of the same or the price of the object of contract. But on the other hand since the contract with the creditor is annulled and cannot be referred the creditor can refer to the second transferee and this seems more reasonable in the case when the second transferee lacks the good will. At the end this issue needs to be mentioned that in case the transaction property from the transferring to the transferee is some money such as the transferring lends some money to the transferee in these cases under the unity of the evidence it can be stated that the creditor as much as the property in the contract can refer to the transferee to vindicate the credit.

\section{Conclusion}

1) On the basis of the latest views of the legislator in the codification of the financial penalty law passed in 2014 in this respect it seems that its expansion has increased compared to previous laws and has not merely lead to the obligatory documents and court judgments but the results are the same as the previous ones in other words the rage of the inclusion is broader but the results are the same as the previous ones and therefore we should consider the relative influence of these contracts. The condition between the sides of the contract is accurate and influential but in contrast the creditor (the third party beneficiary) because of the support of his rights, interests cannot be referred. In the article 21 of the financial penalty administration law passed in 2014 the legislator has recognized both the ownership of the transferee and has authorized the creditor because of the credit from the transferring side refer to the transferee to vindicate his right of the object of the contract.

2) In the relations between the sides of the contract by considering its influence the principle of obligation of contracts are in power and the contract the same as other contracts has all of its influences. Therefore, by the reference of the creditor to the transferee and vindication of his right from the object of contract in cases where the exact object of the contract has been objective on the basis of possession guarantee and unjustified usage guarantee refer to the transferring side. In fact it can be stated that in these cases the transferring sides has earned because of the damage to the transferee. By the reference of the creditor (third person) to the transferee and receiving his properties from him the transferee has earned what he has transferred in the contract between him and the transferring side and has paid in return and in this way his property has reduced and on the other hand the transferring has earned. The reason and cause of the payment of return by the transferee is the receiving of the property that both from the creditor for the credit owing from the creditor is vindicated and therefore, it can be stated that there is no cause to receive return from the transferring side and it can be an instance of the sacred »don't feed on the property of others illegally«.Ayah.

3) First by considering the predictions made in the article 21 of the act passed in 2014 so that there is a chance of vindicating the exact object of contract from the property of the transferee to the creditor and with the assumption that there is no exact object of the contract it might seem that the transferee has a responsibility the 
same as a usurper but this needs to be eradicated from the mind because we cannot ascribe all of the heavy ruling of the usurper for this case therefore in the relation between creditor and the transferee by considering the fact that the creditor does not have the objective right over the property of the debtor and the possession of the transferee is not guaranteed but because of a religious and legal transference cause despite the predictions made by the law maker to vindicate the exact object, the same or the price of it from the property of the transferee his responsibility should not be compared with usurper. In terms of the transferee guarantee about the benefits it seems that we should consider differentiation. It seems difficult to state the fact that transferee is the same as usurper in terms of the exchequer and non-exchequer benefits.

4) In case of the transference of the exact object of contract by the transferee it seems that according to article 21 of the act passed in 2014 the creditor can only refer to the first transferee. But on the other hand it can be stated that given the fact that the contract with the creditor is canceled and cannot be referred to the creditor can also refer to the second transferee and this seems more reasonable in case the second transferee lacks good will.

\section{References}

Abolgasem ben Muhammad Hassan Gilani (MirzayeGomi). (1992). Jama'a al shitat fi Ajwibah al su'alat (Vol. 2). Tehran Keyhan institute, p. 288.

Bojnordiye Mosavi, H. A. B. (1998). Algavaedelfagih (al-Qawaidal Fiqhiyah) (Vol. 2., 1st ed.). Qom Hadi publication.

Darabpur, M. (2008). Outside the contract responsibilities. Tehran Majd publication, p. 291.

Hamid, E., \& Akbari, I. (2010). Occupying guarantee in Islamic jurisprudence and civil law Islamic bases, N.2 43th year, p. 14.

Hosseyni Maragi, M. A. (1996). Alanavin al Fiqhiyah (Vol. 2., 1st ed.). Qom Islamic publications, p. 39.

Karaki, A. H. (1993). Jama'a al maqasid fi sharh al qawa'id (Vol. 4). Qom: Alolbeit publication, p. 246.

Khoie, A. M. (1992). Mesbahalfegahe (Vol. 4., 3rd ed.). Qom vojdani publication, p. 347.

Mirza Hassan, M. N. (1987). Mustadrak al-Wasā'ilwa-mustanbaț al-masā'il (Vol. 17., 1st ed.). Beirut Alolbeit institute Islam, p. 89.

Morteza Ben, M. A. A. (1994). Almakaseb Almoharrame (Vol. 5). Qom, Sheik Ansari ceremony international congress, P. 17.

Muhammad ben, H. B. Y. H. (2008). Idah al fawa'id fi sharhmushkilat al qawa'id (Vol. 1., 1st ed.). Qom Esmailian institute, p. 420.

Muhammad eben Muhammad tagi Bahrololum. (1982). Balgatolfagih (Vol. 1). Tehran, p. 67.

Muhammad ebnemaki Ameli, (ShahidAvval). (1989). Al-Lum'at al-Dimashqiyya, daraltourath- al dar al islamiya, p. 222.

Muhammad Hassan Najafi. (1983). Jawahir al-Kalam fi SharhShara'i' al-Islam (Vol. 22., 7th ed.). Beirut, AltoraseArabi, p. 220.

Muhammad Jafar Langrudi. (2006). Trade and civil law encyclopedia (3rd ed.). Tehran NashreGostar, p. 218.

Muhammad Jafar Langrudi. (2007). A bridged law terminology (Vol. 3). Tehran, GanjeDanesh, under the security of failure in the title.

Muhammad Jafar Langrudi. (2009). Properties law (6th ed.). Tehran: Ganjedanesh library, p. 62.

Muhammad Kazem Ben Hussein Khorasani. (1985). Hashiye Almakaseb. Tehran: Islamic guidance and culture ministry, p. 81 .

Muhammad Kazem Mostafavi. (2000a). Al-Qawaidma'aqaida al Fiqhiyah (4th ed.). Qom Islamic publication, p. 81.

Muhammad Kazem Mostafavi. (2000b). Gaedeye Feghi (4th ed.). Qom Islamic publication, p. 24.

Muhammad Kazem Tabatabaee Yazdi. (2000). Hashiye Makaseb (2nd ed.). Qom, Esmailian, Institute, p. 179.

Muhsen Tabatabai Hakim. (n.d.) Nahjolbalage (Vol. 1). Qom bistodoe Bahman publication, P, 265.

Naser Katuzian. (1988). Moen contracts (Vol. 1., 4th ed.). Tehran, Enteshar publication, p. 226.

Naser Katuzian. (2011). Definite contracts (gifts) (Vol. 3., 14th ed.). Tehran, Ganjedanes, pp.73-74.

Naser Katuzian. (2013). General rules of the contracts (Vol. 4., 7th ed.). Tehran enteshar corporations company, 
p. 79.

Rahim, H. (2009). Unjustified usage adaptive study. Tehran entesha publication, p. 73.

Seyyed Hussein Safaee. (2004). Civil law persons and properties (Vol. 1., 3rd ed.). Tehran Mizan publications.

Seyyed Hussein Safaee. (2007). Essays on civil law and adaptive law (2nd ed.). Quran Mizan publication, p. 370 .

Seyyed Mahdi Navaie. (2009). Gurantee caused by illegal dominance (1st ed.). Qom Bustan institution, p. 164.

Taheri, H. (1997). Civil law (2nd ed.). Qom Islamic publication, p. 309.

Toosi, A. M. (1986). Alkhalaf(Vol. 3., 1st ed.). Qom, Islamic publication office, p. 505.

Tusi, A. A. (2008). Almabsut fi fegheemamiye (Vol. 2., 3rd ed.). Tehran: Alkabemortezavi, p. 237.

Vagef, A. A. M. (2010). Civil law outside the contract. Jungel publication, p. 142.

Zeinodin ben Ali Ameli (ShahidSani). (1992). Masalek al afhamilatanqihsharaye al islam (Vol. 4., 1st ed.). Qom Islamic studies Institute, p. 200.

\section{Copyrights}

Copyright for this article is retained by the author(s), with first publication rights granted to the journal.

This is an open-access article distributed under the terms and conditions of the Creative Commons Attribution license (http://creativecommons.org/licenses/by/4.0/). 